\title{
PENERAPAN METODE MAMDANI UNTUK SISTEM PENDUKUNG KEPUTUSAN PENENTUAN GOLONGAN OBAT SESUAI DENGAN PENYAKIT DIABETES
}

\author{
Jasri 1), Rabby Nazli ${ }^{2)}$ \\ ${ }^{1}$ Program Studi Teknik Informatika, Fakultas Teknik, Universitas Islam Kuantan Singingi \\ Jl. Gatot Subroto Km. 7 Jake, Teluk Kuantan \\ E-mail: jasri.skom@gmail.com \\ ${ }^{2}$ Program Studi Teknik Informatika, Fakultas Teknik, Universitas Islam Kuantan Singingi \\ Jl. Gatot Subroto Km. 7 Jake, Teluk Kuantan \\ E-mail : rabbynazli@gmail.com
}

\begin{abstract}
Abstrak
Diabetes Meletus merupakan salah satu penyakit yang banyak menyababkan kematian. Penggunaan obat yang tidak sesuai dengan dosis penyakit menyebabkan tekanan darah glukosa menjadi tidak normal sehingga sulitnya penderita Deabetes Meletus untuk mendapatkan obat yang sesuai. Untuk itu permasalahan akan diselesaikan dengan metode mamdani dengan beberapa variable yaitu variable input Kadar Glukosa Darah variable output Golongan Obat. Dengan penerapan variable akan mampu menentukan dosis yang sesuai dengan jenis penyakit hingga kadar glukosa darah agar tetap normal. Penggunakan aplikasi ini diperuntukan untuk apoteker hingga bisa dimammfaatkan jika pasien betul betul membutuhkan dosis yang sesuai jika dokter tidak ada di tempat.
\end{abstract}

\section{Kata kunci: Mamdani, Obat, Kadar Glukosa Darah}

\begin{abstract}
Abstrak
Erupted diabetes is one of the diseases that cause many deaths. The use of drugs that are not in accordance with the dose of the disease causes glucose blood pressure to become abnormal so it is difficult for people with diabetes to erupt to get the appropriate medication. For this reason the problem will be solved by the mamdani method with a number of variables, namely the variable input Blood Glucose Level output variable Drug Group. With the application of variables, it will be able to determine the dosage according to the type of disease until the blood glucose level remains normal. The use of this application is intended for pharmacists to be able to use it if the patient really needs the right dose if the doctor is not available.
\end{abstract}

\section{Keyword: Mamdani, Drug, Diabetes Meletus}




\section{PENDAHULUAN}

Klinik armen suheri dalam keadaan sehari hari dibidang kesehatan. Dimana dokter begitu sibuk sehingga sering terjadi penggantian tenaga medis sehingga menyulitkan pasien control, disebabkan pergantian dokter yang ada pada klinik tersebut. Setiap pasien penanganan yang berbeda, mengakibatkan berbedanya pendapat msalah dosis yang dikonsumsi pasien.

Diabetes mellitus adalah penyakit multifaktorial, yang ditandai dengan sindroma hiperglikemia kronis dan gangguan metabolisme karbohidrat, lemak serta protein yang disebabkan insufisiensi sekresi insulin ataupun aktivitas endogen insulin atau keduanya (1). Hiperglikemia yang tidak terkontrol juga dapat menimbulkan banyak penyakit komplikasi seperti neuropati, stroke dan penyakit pembuluh darah perifer (2) (Nany Suryan, dkk, 2016)

Sistem Pendukung Keputusan (SPK) atau Decision Support System, adalah sistem informasi interaktif yang mendukung proses pembuatan keputusan melalui presentasi informasi yang dirancang secara spesifik untuk pendekatan penyelesaian masalah dan kebutuhan-kebutuhan aplikasi para pembuat keputusan, serta tidak membuat keputusan untuk pengguna (Kenneth. E. Kendall dan Julie. E. Kendall, 2003)

Berdasarkan hal diatas, timbul sebuah gagasan untuk menganalisa bagaimana menentukan golongan obat yang sesuai dengan penyakit deabetes. Penelitian ini menggunakan metode Fuzzy Inference Sistem (FIS) untuk menentukan obat yang sesuai untuk menjaga agar tekanan darah penderita penyakit DM, tetap terkontrol dalam keadaan normal.

\section{TINJAUAN PUSTAKA}

\subsection{Fuzzy Logic}

Menurut Wira Buana Pada Jurnal Edik Informatika Fuzzy Logic merupakan adapun tahapan tahapan yang dilakukan. Beberapa model fuzzy logic banyak diterapkan dalam menyelesaikan berbagai permasalahan salah satunya adalah fuzzy Mamdani. Banyaknya jenis telepon seluler yang tersedia dipasaran membuat para konsumen menjadi kesulitan untuk menentukan pilihannya. Permasalahan yang dipilih adalah membangun sistem pendukung pengambilan keputusan untuk membantu memberikan pilihan ponsel bagi para konsumen berdasarkan kriteria-kriteria yang diinginkan oleh konsumen tersebut

\subsubsection{Operator Fuzzy Logic}

Menurut Wira Buana pada jurnal Edik Informatika operator Fuzzy Logic adalah :

1. Operator AND

Operator ini berhubungan dengan operasi interseksi pada himpunan predikat sebagai hasil operasi dengan operator AND diperoleh dengan mengambil nilai keanggotaan terkecil antar elemen pada himpunan-himpunan yang bersangkutan.

$\mu A U B=\min \left(\_A[x], B[y]\right)$

2. Operator OR

Pada himpunan fuzzy, operator OR diperlihatkan dengan derajat keanggotaan 
maksimum dari kedua himpunan. Operator OR pada himpunan fuzzy bekerja sesuai dengan himpunan klasik 0 OR 1, yang menghasilkan nilai 1 . Operator ini dapat dimodelkan menjadi:

$$
(A A N D B)=\max (\quad(A), \quad(B))
$$

3. Operator NOT

Operator NOT himpunan fuzzy adalah negasi dari himpunan. Operator ini dapat dimodelkan menjadi:

$$
(\text { NOT A) }=1-\quad(A) .
$$

\subsubsection{Definisi Sistem Pendukung Keputusan}

Menurut Kenneth. E. Kendall pada jurnal Teknik Informasi Sistem Pendukung Keputusan (SPK) atau Decision Support System, adalah sistem informasi interaktif yang mendukung proses pembuatan keputusan melalui presentasi informasi yang dirancang secara spesifik untuk pendekatan penyelesaian masalah dan kebutuhan-kebutuhan aplikasi para pembuat keputusan, serta tidak membuat keputusan untuk pengguna (Fahmy Umar)

\subsubsection{Definisi Deabetes}

Diabetes mellitus adalah penyakit multifaktorial, yang ditandai dengan sindroma hiperglikemia kronis dan gangguan metabolisme karbohidrat, lemak serta protein yang disebabkan insufisiensi sekresi insulin ataupun aktivitas endogen insulin atau keduanya. Hiperglikemia yang tidak terkontrol juga dapat menimbulkan banyak penyakit komplikasi seperti neuropati, stroke dan penyakit pembuluh darah perifer (Nany Suryan, dkk, 2016)

\subsubsection{Metode Mamdani}

Metode Mamdani sering juga dikenal dengan nama Metode Max-Min. Metode ini diperkenalkan oleh Ebrahim Mamdani

\subsubsection{Fungsi Keanggotaan}

Representasi bentuk kurva membership function dapat dibagi sebagai berikut (Haryanto, 2015).

1. Representasi Kurva Segitiga

Kurva Segitiga pada dasarnya merupakan gabungan antara 2 garis (linier). Perhatikan Gambar 2.3. 


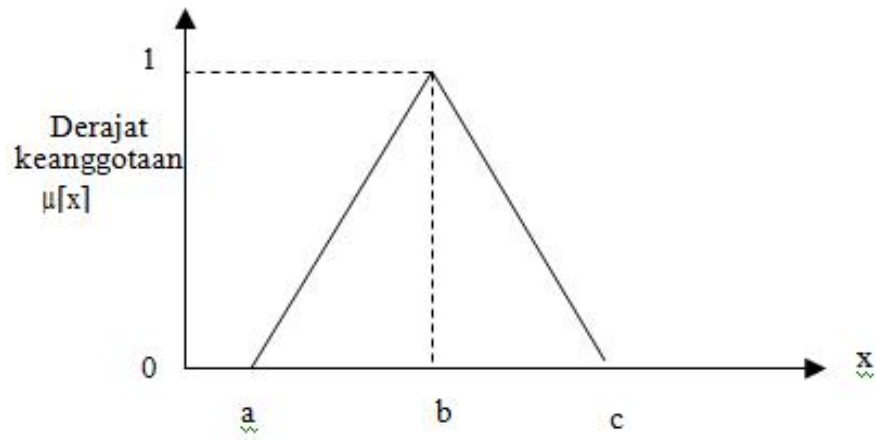

Gambar 2.3 Kurva Segitiga.

Fungsi Keanggotaan

$$
\mu(x ; a, b, c)=\left\{\begin{array}{cc}
0 & x<a \\
\frac{x-a}{b-a} & a \leq x \leq b \\
c-x & b<x \leq c \\
c-b & x>c
\end{array}\right.
$$

\section{METODOLOGI PENELITIAN}

Berdasarkan analisa-analisa yang di uraikan maka dapat di lihat tahapan penelitian ini pada gambar 3.1.

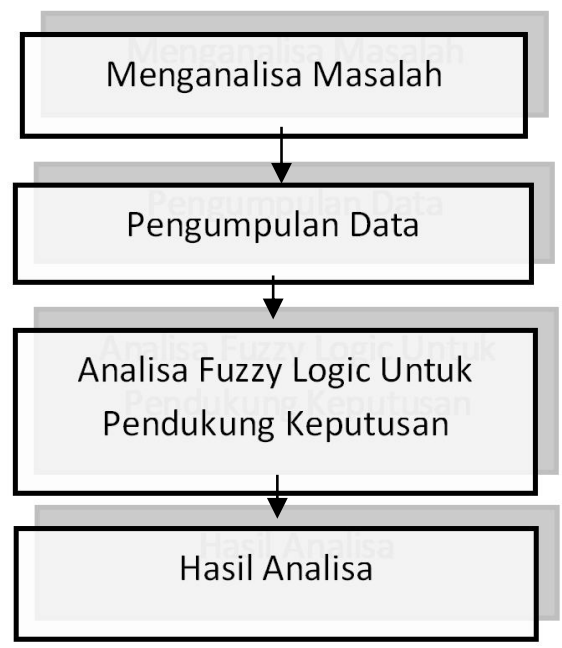

Gambar 3.1 Prosedur Penelitian

\subsection{Menganalisa Masalah}

Langkah menganalisa masalah adalah langkah untuk dapat memahami masalah yang telah ditentukan dalam ruang lingkup atau batasannya. Dengan survey langsung menemui pakar yang ada di lapangan yaitu dokter yang telah memahami tentang dosis oata yang sesuai. Dengan menganalisa masalah yang ditentukan tersebut, maka masalah dapat dipahami dengan baik. Masalah yang timbul sekarang adalah bagaimana menentukan golongan obat yang sesuai untuk menjaga agar tekanan darah tetap terkontrol menggunakan fuzzy Logic. 


\subsection{Pengumpulkan Data}

Dalam pengumpulan data dan informasi, pada tahap ini dilakukan untuk mengetahui mengenai sistem yang diteliti. Dari data dan informasi yang dikumpulan akan didapat data untuk pendukung penelitian. Metode yang digunakan penulis untuk pengumpulan data dengan berbagai metode sebagai berikut :

a. Observasi

Melakukan pengamatan langsung di tempat penelitian untuk mengetahui secara jelas dan terinci permasalahan yang ada. Dengan menanyakan kepuasan baik kepuasan pasien maupun tindak lanjut dari dokter bagaimana cara menangani penyakit yang diderita oleh pasien. Pengamatan langsung dilalukan pada Klinik Armen Suheri.

b. Interview

Dilakukan untuk memperoleh informasi atau data yang dibutuhkan dengan cara melakukan wawancara langsung pada bagian yang terkait yaitu pada Staf Klinik, dokter maupun pasien yang berkunjung ke klinik tersebut agar pemberian tool pada metode mamdani sesuai dengan vaiable variable yang ada dalam metode yaitu jenis penyakit kadar gula glukosa maupun jenis dosis obat yang sesuai dengan golongan kadar gula glukosa tersebut .

c. Studi Literatur

Dalam metode ini informasi dikumpulkan dengan membaca jurnal dan buku - buku yang berhubungan dengan tesis untuk menunjang dalam melakukan analisa terhadap data dan informasi. Di antara buku yang berkaitan dengan fuzzyLogic dan jurnal yang berkaitan dengan tesis.

\subsection{Analisa Fuzzi Logic}

Pada proses analisa data menggunakan Fuzzy Logic ini berguna untuk menerapkan variabel-variabel Fuzzy Logic untuk menentukan golongan obat yang sesuai agar kadar gula tetap normal. Dimana beberapa nilai fuzzy yang telah didapat dari pakar akan di masukan kedalam variable-variabel fuzzy hingga memudahkan dalam mesaukan tools yang ada.

\subsection{Pengujian}

Menampilkan hasil pengolahan data, proses ini merupakan proses yang terakhir dari rangkaian dalam sistem ini. Proses ini akan menampilkan tabel obat yang sesuai terhadap tekanan darah agar tetap terkontrol, Adapaun mekanisme pengujian yang akan dilakukan adalah Pengujian manual, di mana dalam mencari nilai variabel input dilakukan proses fuzzyfikasi dengan mencari nilai derajat keanggotaan masing - masing criteria input. Proses pencarian derajat keanggotaan dengan rumus kurva segitiga.

\subsection{Hasil}

Dari pengujian dengan menerapkan variabel - variabel fuzzy logic maka dapat diketahui golongan obat yang sesuai untuk penyakit DM akar tekanan kadar glukosanya tetap normal. 


\section{HASIL DAN PEMBAHASAN}

Berdasarkan permaslahan yang ada maka dapat kita ketahui sebagaiberikut :

Tabel 3.1 Himpunan Input Fuzzy

\begin{tabular}{|c|c|c|c|c|}
\hline \multicolumn{2}{|c|}{ Variabel } & \multicolumn{3}{|c|}{ Himpunan Input Fuzzy } \\
\hline Nama & Notasi & Nama & Notasi & Domain \\
\hline \multirow{3}{*}{$\begin{array}{c}\text { Kada Glukosa } \\
\text { Darah }\end{array}$} & \multirow{3}{*}{$\mathrm{A}$} & Rendah & $\mathrm{R}$ & {$[70-90]$} \\
\cline { 3 - 5 } & & Sedang & $\mathrm{S}$ & {$[90-130]$} \\
\cline { 3 - 5 } & & Tinggi & $\mathrm{T}$ & {$[130-190]$} \\
\cline { 2 - 4 } & Sangat Tinggi & ST & {$[190-300]$} \\
\hline
\end{tabular}

Tabel 3.2 Himpunan Output Fuzzy

\begin{tabular}{|c|c|c|c|c|}
\hline \multicolumn{2}{|c|}{ Variabel } & \multicolumn{3}{|c|}{ Himpunan Input Fuzzy } \\
\hline Nama & Notasi & Nama & Notasi & Domain \\
\hline \multirow{3}{*}{ Golongan Obat } & \multirow{3}{*}{$\mathrm{B}$} & Sulfonilurea & SF & {$[70-90]$} \\
\cline { 3 - 5 } & & Tiazolidindion & TD & {$[90-130]$} \\
\cline { 3 - 5 } & & Penghambat Glukosa & PG & {$[130-190]$} \\
\cline { 2 - 5 } & Insulin & IS & {$[190-300]$} \\
\hline
\end{tabular}

\subsection{Fuzzyfikasi}

Adapun tujuannya dalam penelitian ini berupa fuzzyfikasi yang akan dipaparkan dibawah ini:

Contoh :

Kadar Glukosa Darah : 75 (Rendah)

$$
\begin{aligned}
82 & : 75-70 / 90-80 \\
& : 0.5
\end{aligned}
$$

\subsection{Inference}

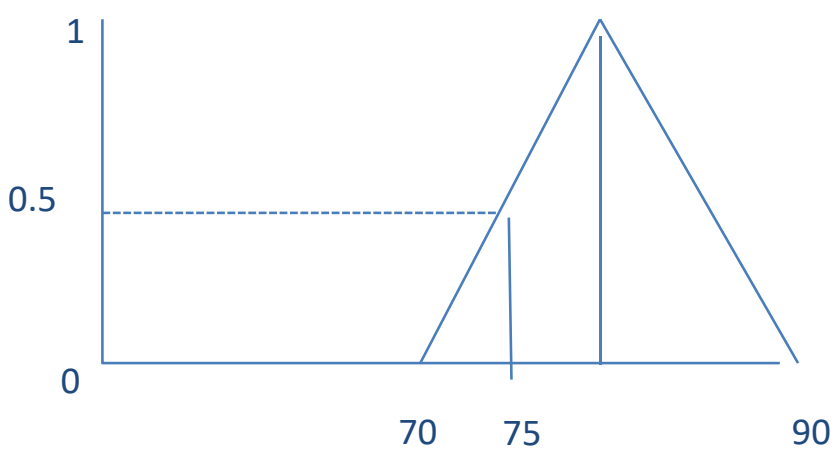

Inference adalah cara dalam menentuakan nilai min untuk setiap aturan yang berlaku pada fuzzy

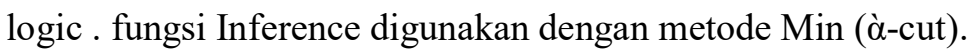

$$
\begin{aligned}
\alpha \text { prediket } & =\mu \text { Rendah } \\
& =\text { Min } \mu \text { Prehipertensi (75) }
\end{aligned}
$$




$$
\begin{aligned}
& =\operatorname{Min}(0,5) \\
& =0,5
\end{aligned}
$$

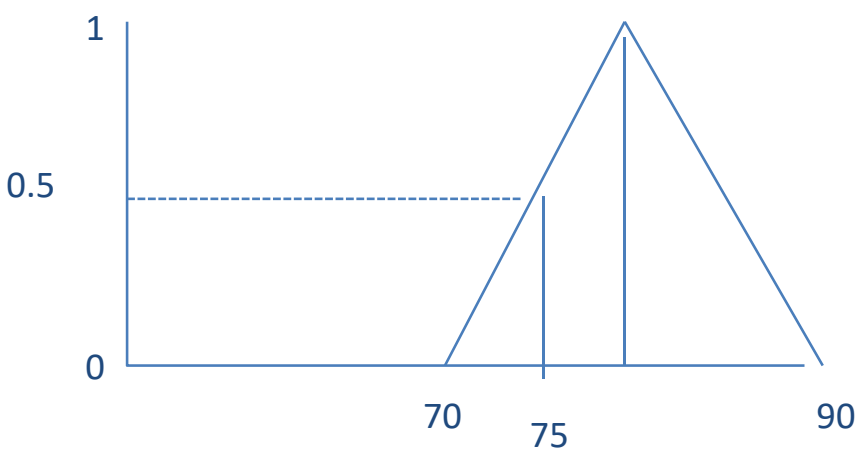

Gambar 4.2 Kadar Glukosa Darah

\subsection{Defuzzyfikasi}

Pada proses ini peneliti menggunakan Center Of Gravity(COG) di mana Kadar Glukosa Darah, dapat dirumusnya adalah rumus sebagai berikut:

$$
\begin{aligned}
& Z^{*}=\frac{\sum_{90}^{70} z j u(2 j)}{\sum_{1}^{n} u(2 j)} \\
& =\frac{70 * 0+71 * 0.5+72 * 0.5+\cdots+89 * 0.5+90 * 0}{0+(20 * 0.5)+0} \\
& =80
\end{aligned}
$$

\section{KESIMPULAN}

Berdasarkan penelitian yang diterapkan kedalam metode mamdani untuk menentukan golongan obat yang sesuai dengan kadar gula glukosa. Jadi kesimpulan nya adalah Metode mamdani dapat menentukan golongan obat yang sesuai dengan penyakit hipertensi agar tekanan hipertensi tetap normal setelah kenggotaan fuzzy diterapkan pada Fuzzy Logic.

\section{UCAPAN TERIMAKASIH}

Alhamdulillah, puji syukur selalu peneliti panjatkan kepada Allah SWT yang telah menganugerahkan rahmat, taufik dan berkah-Nya sehingga peneliti dapat menyelesaikan dengan baik. Peneliti juga ingin menyampaikan ucapan terimakasih yang tak terhingga dan penghargaan setinggi-tingginya kepada Civitas Akademika Universitas Islam Kuantan Singingi. 


\section{DAFTAR PUSTAKA}

Buana, W. "Penerapan Fuzzy Mamdani Untuk Sistem Pendukung Keputusan Pemilihan Telepon Seluler" Jurnal Edik Informatika Penelitian Bidang Komputer Sains dan Pendidikan Informatika, ISSN 2407-049

Fahmy Umar, F dan Widjianto., dan Dinny Wahyu Widarti, D, W. "Sistem Pendukung Keputusan Keputusan Pemilihan Laptob Menggunakan Metode Fuzzy Data Base Model Tahani Berbasis Web “ Jurnal Teknologi Informasi Vol. 6 No. 2

Haryanto, H., E dan Nasarim F. (2015). "Penerapan Metode Fuzzy Mamdani Dalam Memprediksi Tingginya Pemakaian Listrik (Studi Kasus Kelurahan ABC" Seminar Nasional Teknologi Informasi dan Multimedia 2015 6-8 Februari (2015), ISSN 2302-3805

Jasri. (2018). "Menentukan Jenis Penyakit Menggunakan Metode Mamdani Dengan Golongan Obat Yang Sesuai” Jurnal Jurnal Teknologi dan Open Source, Vol 1 No.1 Juli 2018

Suryani, N., Pramono., dan Septiana, H. (2016)"Diet dan Olahraga sebagai Upaya Pengendalian Kadar Gula Darah pada Pasien Diabetes Melitus Tipe 2 di Poliklinik Penyakit Dalam RSUD Ulin Banjarmasin Tahun 2015” Jurnal Jurkessia, Vol. VI, No. 2, Maret 2016 